\title{
Changes in Cyanoprokaryote Populations, Microcystis Morphology, and Microcystin Concentrations in Lake Elphinstone (Central Queensland, Australia)
}

\author{
Susan H. White, Larelle D. Fabbro, Leo J. Duivenvoorden \\ Freshwater Ecology Group, Centre for Environmental Management, Central Queensland \\ University, Rockhampton QLD, Australia 4702
}

Received 24 July 2003; revised 3 September 2003; accepted 9 September 2003

\begin{abstract}
Lake Elphinstone is a tropical inland water body in the far north of the Fitzroy Catchment in Central Queensland, Australia, and has experienced recurrent toxic cyanoprokaryote blooms since 1997. This article reports on an examination of the environmental conditions of the lake and the concurrent cyanoprokaryote species together with their toxicity. The lake was sampled three times during periods of high cyanoprokaryote cell concentrations. Successive changes in the dominant Microcystis species were accompanied by variation in the concentration of the hepatotoxin microcystin. Environmental parameters recorded during dominance by both the highly toxic species Microcystis panniformis and the nontoxic $M$. botrys are provided. Nutrient status, temperature, and light conditions were associated with species change within the blooms. Variation of microcystin concentrations coincided with speciation change (i.e., morphological variation) within the blooms. Also discussed is the environmental impact of toxin production by $M$. panniformis with respect to influence on cell division, energy states, and toxin photodegradation. Lake Elphinstone is the first Australian location reported to have M. panniformis. () 2003 Wiley Periodicals, Inc. Environ Toxicol 18: 403-412, 2003.
\end{abstract}

Keywords: Cylindrospermopsis; Lyngbya; periodicity; cylindrospermopsin; nutrients; iron; shallow lakes

\section{INTRODUCTION}

The combination or synergy of environmental factors required to trigger speciation change in toxic algal blooms varies depending on the water body and species. The exact

Correspondence to: Susan White, c/o School of Biological and Environmental Sciences, Building 6, Central Queensland University, Bruce Highway, Rockhampton, Queensland 4702, Australia; E-mail: s.white@cqu.edu.au

Contract grant sponsor: Nebo Shire Council (Lake Elphinstone Alliance).

Published online in Wiley InterScience (www.interscience.wiley.com). DOI 10.1002/tox.10142

(C) 2003 Wiley Periodicals, Inc. functioning of these factors in tropical lakes remains poorly understood (Dokulil \& Teubner, 2000). Temperate studies regarding blooms have limited applicability in tropical environments (Huszar et al., 1998), and the understanding of phytoplankton dynamics in southern hemisphere lakes remains inadequate (Harding, 1997). Cyanoprokaryote toxicity is variable both within and between blooms (Falconer, 2001; Ressom et al., 1994). Algal cell concentrations are not necessarily correlated with the toxicity of blooms, as both toxic and nontoxic cyanoprokaryotes can coexist (DeMott \& Moxter, 1991). Toxin content may be influenced by physicochemical parameters such as light penetration, nutrient availability, $\mathrm{pH}$, and temperature (Orr \& Jones, 1998); 


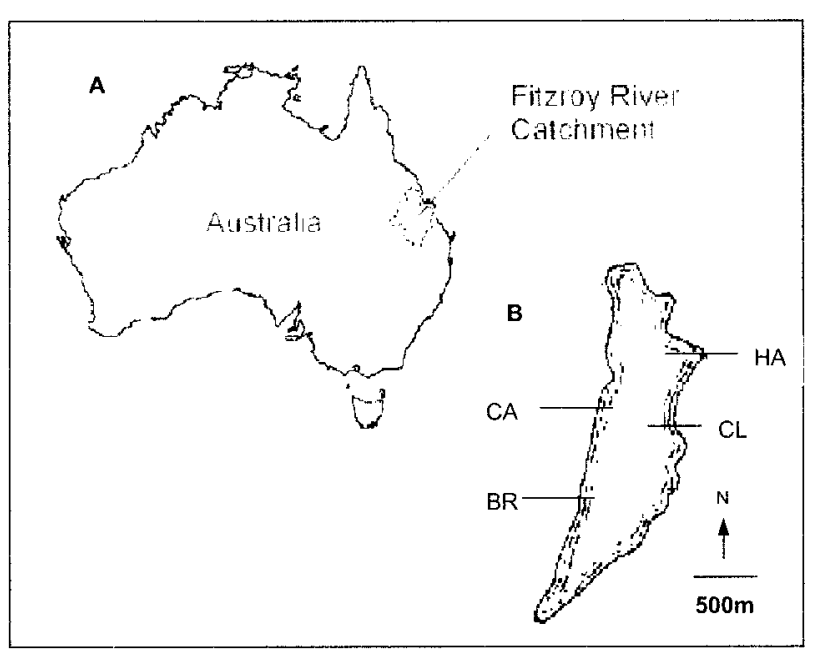

Fig. 1. (A) Location of Lake Elphinstone in the Fitzroy Catchment, Australia. (B) Sampling sites at Lake Elphinstone (CA-camping area; HA-homestead area, BR-boat ramp, $\mathrm{CL}-$ Center of lake).

species and strain of cyanoprokaryote and bloom heterogeneity (Lirås et al., 1998); factors contributing to degradation of toxin (Chiswell et al., 1999; Jones et al., 1994) and, potentially, culture age (DeBernadi \& Guissani, 1990). This study of Lake Elphinstone contributes to the knowledge base regarding inland tropical lakes and the factors promoting algal blooms and their accompanying toxicity. Descriptions of the environmental conditions influencing the cyanoprokaryote blooms at Lake Elphinstone are of particular value for the future management of toxic algal blooms, particularly from the presence of Microcystis panniformis.

\section{MATERIALS AND METHODS}

\section{Study Area}

Lake Elphinstone is a tropical, inland freshwater lake in the far north of the Fitzroy Catchment in Central Queensland, Australia (Fig. 1). It is a shallow natural lake (mean depth during this study was $1.3 \mathrm{~m}$ ), approximately $3 \mathrm{~km}$ long and less than $1 \mathrm{~km}$ wide. There are no significant inflows or outflows, and the lake experiences a tropical climate with highly variable rainfall averaging $666 \mathrm{~mm}$ annually. The lake has experienced recurrent toxic cyanoprokaryote blooms since 1997. Studies of the phytoplankton formed part of a limnological study of Lake Elphinstone conducted between March and July 2002, which (along with data collected in previous years) found Lake Elphinstone to be a warm polymictic lake with diurnal stratification, and high light-attenuation values (maximum euphotic depth: $54 \mathrm{~cm}$ ). Periods of extreme nutrient enrichment, with maximum total nitrogen concentrations above $3000 \mu \mathrm{g} \mathrm{L}^{-1}$ and total phosphorus concentrations above $200 \mu \mathrm{g} \mathrm{L}^{-1}$ were also recorded during 2002.

\section{Field Sampling and Laboratory Analyses}

Field trips were conducted at the lake on March 20-22, May 13-14, and July 22-23, 2002, and four study sites identical to those used for physical and chemical sampling were used for phytoplankton sampling - boat ramp (BR), camping area (CA), center of lake (CL), and homestead area (HA). This enabled correlations to be made with physical, chemical, and phytoplankton data. Light, temperature, and oxygen data were collected.

Characteristics of the phytoplankton community studied were biovolume, toxicity, and environmental variables. For taxonomic work, phytoplankton tows were conducted on the eastern and western sides of the lake using a $25-\mu \mathrm{m}$ net, with the fresh (unpreserved) samples placed on ice. Phytoplankton were identified to the species or subspecies level using a Zeiss Axioskop microscope equipped with an MC 80 photomicroscope, drawing tube, and Neofluar and Achrostigmat objectives. Identification was guided by descriptions of Komárek et al. (2001), Baker and Fabbro (1999), Gell et al. (1999), Ling and Tyler (1986), Findlay and Kling (1979), Prescott (1978, 1951), and the Fritsch Collection. A pictorial reference collection was compiled using the drawing tube supplemented with photomicrography and is currently housed in the Freshwater Ecology Group Laboratory at Central Queensland University.

To obtain algal concentration data (cells $\mathrm{mL}^{-1}$ ), a phytoplankton sample representing the entire water column was collected at each site using an integrated tube (hose-pipe) sampler. From each, two subsamples were taken and preserved with $1 \%$ Lugol's iodine solution prepared using $10 \mathrm{~g}$ of pure iodine, $20 \mathrm{~g}$ of potassium iodide, $200 \mathrm{~mL}$ of distilled water, and $20 \mathrm{~g}$ of glacial acetic acid (Hötzel and Croome, 1998). Depth samples $(1 \mathrm{~m})$ were also taken at each site using a Van Dorn bottle and preserved. Surface samples (0.1 $\mathrm{m}$ depth) were collected by hand on the second and third trips only. One subsample each of the depth and surface samples was taken for cell counts. Cell counts were performed using the Sedgewick-Rafter Counting Chamber method according to Hötzel and Croome (1998). This involved placing $1 \mathrm{~mL}$ of subsample into a calibrated chamber and allowing it to sediment for at least $30 \mathrm{~min}$. Following this, 100 units (cells, filaments, trichomes, or colonies) of the cyanoprokaryote, chlorophyte, cryptophyte, xanthophyte, euglenophyte, and bacillariophyte groups or 25 of the chamber squares were counted, whichever was reached first. Quantity of cells in large colonies was estimated by measuring the colony and using the known dimensions of cells to calculate the cell number.

Samples for toxin analysis were collected by hand in glass bottles at a depth of $0.1 \mathrm{~m}$ near the boat ramp site and 
placed in the dark on ice to prevent breakdown of toxins. When evident, samples of concentrated algal colonies, surface scums, and/or foam were also collected by hand or phytoplankton tow. Samples were sent to the Australian Water Quality Centre (Bolivar) or the National Centre for Ecotoxicity Testing (Brisbane) for analysis of microcystin (MC) and cylindrospermopsin (CYN) content. Microcystins were analyzed using preconcentration and high-performance liquid chromatography (HPLC) with diode array detection. Cells were lysed by ultrasonication before analysis. Cylindrospermopsin samples were frozen and thawed to lyse cells and analyzed using HPLC/electrospray/tandem mass spectrometry.

\section{RESULTS}

\section{Phytoplankton Species Composition}

In all, 53 taxa from the lake were recorded, including 15 cyanoprokaryotes, 26 chlorophytes, 5 cryptophytes, 4 bacillariophytes, 2 euglenophytes, and 1 xanthophyte. Dominant cyanoprokaryote genera included various Microcystis Kützing, Raphidiopsis mediterranea Skuja (Cylindrospermopsis), Lyngbya Lagerheim, and Geitlerinema unigranulatum (Singh) Komárek and Azevedo, whereas Centritractus Lemmermann and Cryptomonas Ehrenberg represented large proportions of the xanthophyta and cryptophyta, respectively. Dominant chlorophytes included Pediastrum, Scenedesmus, and Staurastrum. Bacillariophytes and euglenophytes were generally minor in concentration, represented mostly by Aulacoseira and species of Euglena or Trachelomonas, respectively.

Professor Jiri Komárek identified Microcystis panniformis (Komárek et al., 2001) from the lake during February 2001, making Lake Elphinstone the first documented Australian location for this highly toxic species. Specimens taken from Lake Elphinstone were in agreement with the descriptions of Komárek et al. (2001), with evenly and densely arranged cells occurring on surface layers of colonies (Plates 1 and 2). However, cells were 4.5-6.0 $\mu \mathrm{m}$ in diameter (average $5 \mu \mathrm{m}$ ), slightly larger than those recorded by Komárek et al. (2001).

\section{Cell Concentrations}

Algal cell concentrations varied according to sampling site, date, and position of sampling in the water column [Fig. $2(\mathrm{a}-\mathrm{c})]$. Maximum cell concentration was recorded at $3.04 \times 10^{5}$ cells $\mathrm{mL}^{-1}$ during March, $3.93 \times 10^{5}$ cells $\mathrm{mL}^{-1}$ during May, and only 1280 cells $\mathrm{mL}^{-1}$ in July. Samples collected from the eastern side of the lake [homestead area (HA) and center of lake (CL)] were usually characterized by lower cell concentrations in comparison to the western side [camping area (CA) and boat ramp (BR)].

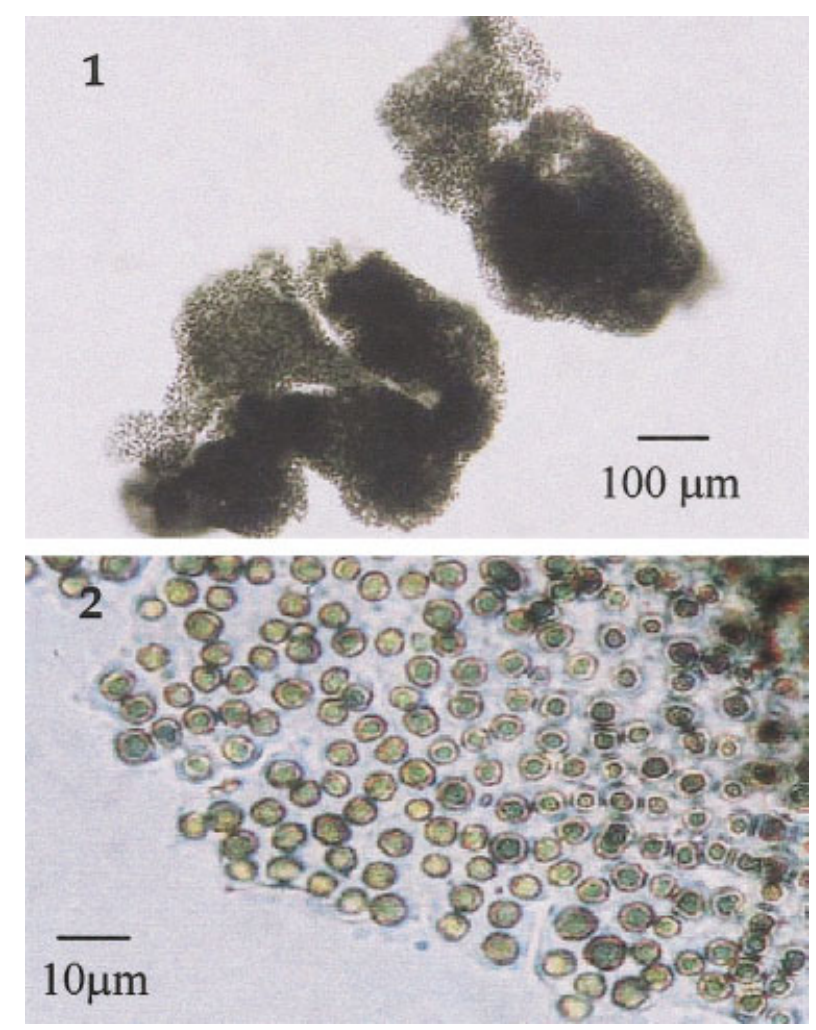

Plates 1 and 2. Microcystis panniformis (Note: Plate 1 preserved with Lugol's iodine, Plate 2 is a fresh mount). [Color figure can be viewed in the online issue, which is available at www.interscience.wiley.com.]

Cyanoprokaryotes dominated the surface, hosepipe, and Van Dorn samples during March and May (Fig. 2), whereas chlorophytes, bacillariophytes, and xanthophytes became more common in July, especially in subsurface waters [Fig. 2(c)]. Blooms featured a variety of codominant cyanoprokaryote species (Fig. 3). M. botrys, G. unigranulatum, and $R$. mediterranea (Cylindrospermopsis) codominated during March, whereas Lyngbya sp. and Cylindrospermopsis raciborskii (Wolosz.) Seenaya and Subba Raju were also present. However, a transition to numerical dominance of M. panniformis occurred in May, particularly at the surface, with $M$. panniformis accounting for $97.5 \%$ of cells in the CA surface sample. However, 1-m depth samples recorded comparatively lower overall cell concentrations for all groups during May [ $<10000$ cells $\mathrm{mL}^{-1}$, Fig. 2(c)]. Low overall cyanoprokaryote concentrations (generally $<1000$ cells $\mathrm{mL}^{-1}$ ) were recorded in July, evidencing the collapse of the bloom prior to sampling. A variety of plankton groups were noted, in contrast to the earlier dominance of cyanoprokaryotes (Fig. 2).

\section{Toxicity}

The results of the MC and CYN analyses showed dramatic variation between samples collected from Lake Elphinstone 

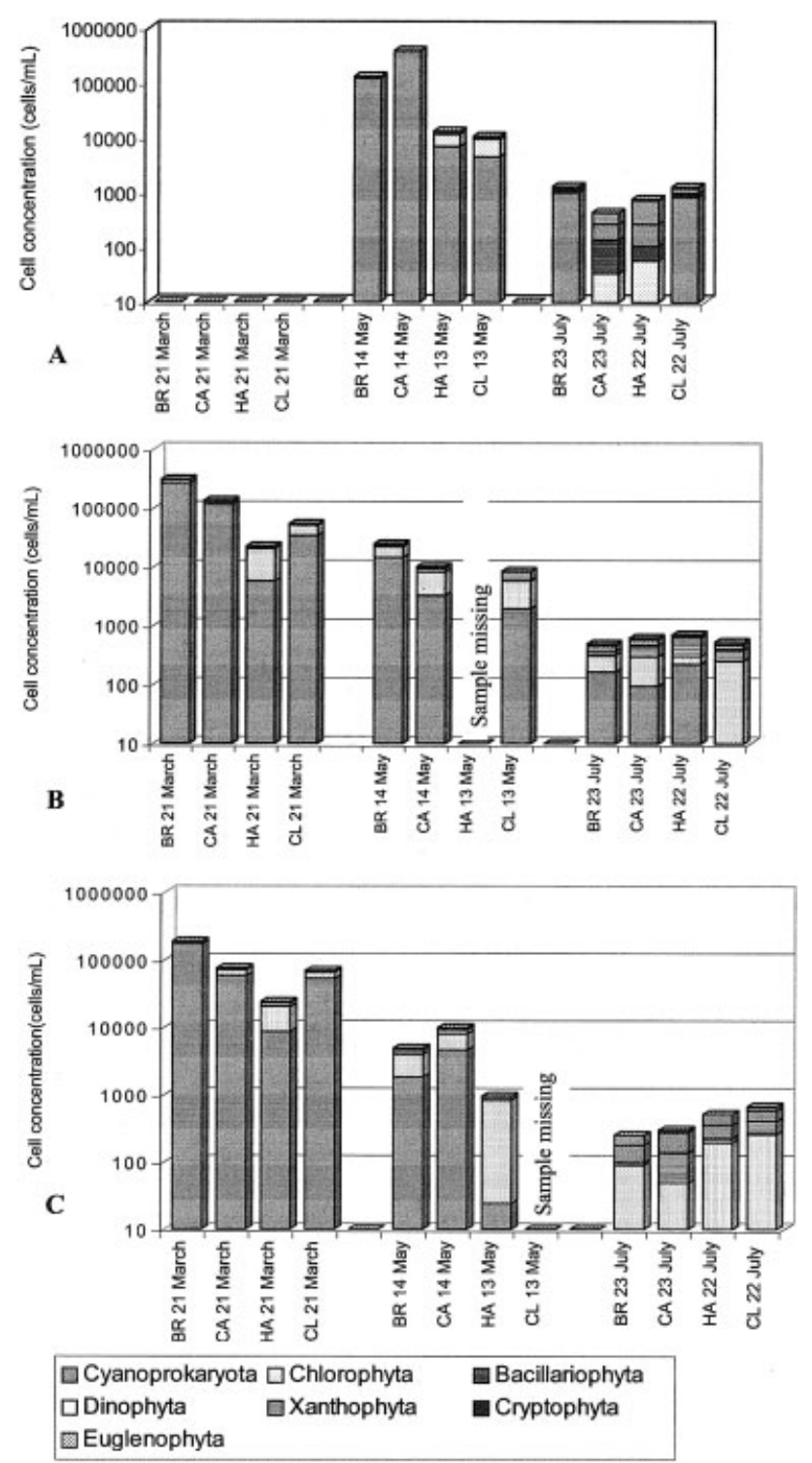

Fig. 2. Cell concentration data for samples collected at Lake Elphinstone: (A) Surface samples, (B) Hosepipe samples, (C) 1-m depth Van Dorn samples (CA-camping area; HA - homestead area, BR-boat ramp, CL-center of lake). Note: no surface samples were collected in March; and cell counts listed for hosepipe samples are the average of two subsample counts.

(Table I). MC was not present when $M$. botrys was dominant during March. In May a scum sample of predominantly $M$. panniformis contained an exceptionally high MC concentration $\left(2500 \mu \mathrm{g} \mathrm{L}^{-1}\right)$. Some CYN was also detected $\left(0.3 \mu \mathrm{g} \mathrm{L}^{-1}\right)$. A foam sample collected simultaneously had much lower MC concentration $\left(10 \mu \mathrm{g} \mathrm{L}^{-1}\right)$, and no intact cells were identified from the sample (Table I). The high MC toxicity during May prompted closure of Lake Elphinstone by public health authorities.

Thick surface scum was not visible at the sampling site during July because of the collapse of the bloom. In the toxin sample both $\mathrm{MC}$ and $\mathrm{CYN}$ concentrations were below detection limits, and the cell count was nil, although many partially decomposed Microcystis colonies were evident. However, a net sample of floating colonies collected near the same site contained $1000 \mu \mathrm{g} \mathrm{L}^{-1} \mathrm{MC}$ and high $M$. panniformis cell concentrations.

\section{Effects of Environmental Conditions}

The environmental conditions recorded in March and May, which corresponded with dominance of $M$. botrys and $M$. panniformis, respectively, are described in Table II. Light, temperature, and oxygen profiles are also provided for the boat ramp sampling site for dates as close as possible to those of the toxicity sampling [Fig. 4(a, b)].
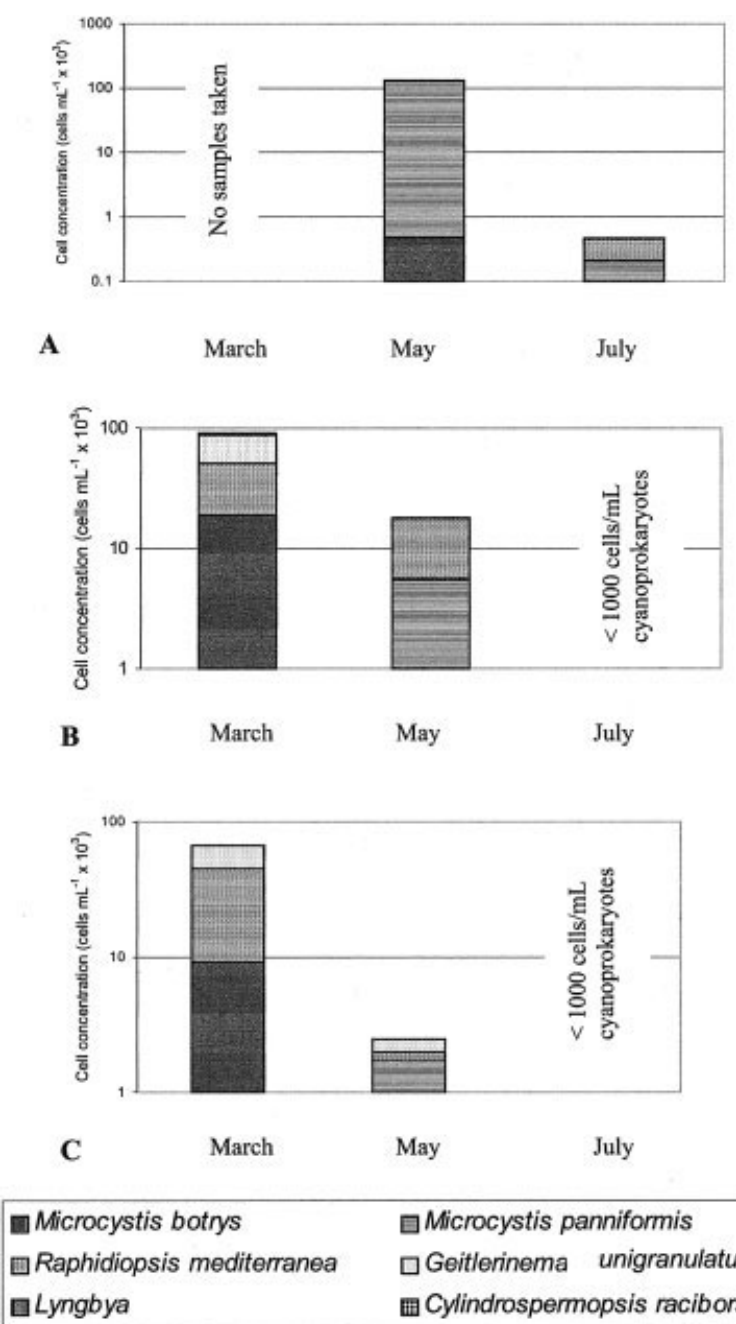

$\square$ Microcystis panniformis $\square$ Geitlerinema unigranulatum 田Cylindrospermopsis raciborskii

Fig. 3. Cell concentrations for dominant cyanoprokaryote species at Lake Elphinstone: (A) Surface samples, (B) Hosepipe samples, (C) 1-m depth Van Dorn samples. Values are the average of four lake sampling sites. Note: No surface samples collected in March. 
TABLE I. Cyanoprokaryote species composition and toxin levels of surface samples collected at Lake Elphinstone 2002

\begin{tabular}{|c|c|c|c|c|c|}
\hline & $\begin{array}{l}\text { March } 23 \\
\text { (surface) }\end{array}$ & $\begin{array}{c}\text { May } 14 \\
\text { (surface scum) }\end{array}$ & $\begin{array}{l}\text { May } 14 \\
\text { (foam) }\end{array}$ & $\begin{array}{l}\text { July } 23 \\
\text { (surface) }\end{array}$ & $\begin{array}{c}\text { July } 23 \\
\text { (net sample) }^{\mathrm{a}}\end{array}$ \\
\hline $\begin{array}{l}\text { Total cell concentration } \\
\quad\left(\text { cells } \mathrm{mL}^{-1}\right)\end{array}$ & $4.24 \times 10^{5}$ & $2.19 \times 10^{6}$ & 0 & 0 & $1.27 \times 10^{6}$ \\
\hline $\begin{array}{l}\text { Relative abundance of } \\
\text { M. botrys }(\%)\end{array}$ & 81 & 0 & $\mathrm{n} / \mathrm{a}$ & $\mathrm{n} / \mathrm{a}$ & 0 \\
\hline $\begin{array}{l}\text { Biovolume of } M \text {. botrys } \\
\quad\left(\mu \mathrm{m}^{3} \times 10^{6}\right)\end{array}$ & 62.2 & 0 & $\mathrm{n} / \mathrm{a}$ & $\mathrm{n} / \mathrm{a}$ & 0 \\
\hline $\begin{array}{l}\text { Relative abundance } M . \\
\text { panniformis }(\%)\end{array}$ & 0 & 100 & $\mathrm{n} / \mathrm{a}$ & $\mathrm{n} / \mathrm{a}$ & 100 \\
\hline $\begin{array}{l}\text { Biovolume of } M \text {. panniformis } \\
\quad\left(\mu \mathrm{m}^{3} \times 10^{6}\right)\end{array}$ & 0 & 144 & $\mathrm{n} / \mathrm{a}$ & $\mathrm{n} / \mathrm{a}$ & 83.3 \\
\hline Raphidiopsis mediterranea (\%) & $<1$ & 0 & $\mathrm{n} / \mathrm{a}$ & $\mathrm{n} / \mathrm{a}$ & 0 \\
\hline Lyngbya sp. (\%) & 17.5 & 0 & $\mathrm{n} / \mathrm{a}$ & $\mathrm{n} / \mathrm{a}$ & 0 \\
\hline Microcystin $(\mu \mathrm{g} / \mathrm{L})$ & 0 & 2500 & 10 & 0 & 1000 \\
\hline Cylindrospermopsin $(\mu \mathrm{g} / \mathrm{L})$ & $\mathrm{b}$ & 0.3 & 0.2 & 0 & 0 \\
\hline
\end{tabular}

n/a: not applicable, no intact cells counted.

${ }^{\text {a }}$ Isolated surface colonies collected via phytoplankton tow.

b Not tested.

The most dramatic changes in the physical and chemical parameters between these months were in temperature, light, and nutrient conditions. Average surface water temperature dropped from $27.8^{\circ} \mathrm{C}$ in March to $22.3^{\circ} \mathrm{C}$ in May. Euphotic depth $\left(K_{e u}\right)$ also decreased, from $54 \mathrm{~cm}$ (March) to $33 \mathrm{~cm}$ (May), whereas Secchi disc extinction depths nearly halved (from 26 to $14 \mathrm{~cm}$ ). Weak oxyclines were evident for the mornings of both sampling dates [Fig. 4(a, b)]. With respect to nutrients, both total nitrogen (TN) and total phosphorus (TP) values increased in May. However, of

TABLE II. Variables measured at Lake Elphinstone during dominance of $M$. botrys in March and dominance of M. panniformis in May of 2002

\begin{tabular}{|c|c|c|c|c|c|c|c|c|c|c|}
\hline & \multicolumn{2}{|c|}{ Boat Ramp } & \multicolumn{2}{|c|}{ Camping Area } & \multicolumn{2}{|c|}{$\begin{array}{c}\text { Homestead } \\
\text { Area }\end{array}$} & \multicolumn{2}{|c|}{$\begin{array}{c}\text { Center of } \\
\text { Lake }\end{array}$} & \multicolumn{2}{|c|}{ Average $\pm S D$} \\
\hline & March & May & March & May & March & May & March & May & March & May \\
\hline $\begin{array}{l}\text { M. botrys (cells } \mathrm{mL}^{-1} \text {, } \\
\text { hosepipe) }\end{array}$ & 24120 & 60 & 39320 & 0 & 0 & - & 12080 & 0 & $1880 \pm 16812$ & - \\
\hline $\begin{array}{l}\text { M. panniformis (cells } \\
\mathrm{mL}^{-1}, \text { surface) }\end{array}$ & 0 & 119,600 & 0 & 383,950 & 0 & 5800 & 0 & 3985 & 0 & $128,334 \pm 178,786$ \\
\hline Surface temperature $\left({ }^{\circ} \mathrm{C}\right)$ & 26.9 & 23.3 & 29.5 & 20.8 & 27.8 & 23.3 & 27.2 & 22.0 & $27.8 \pm 1$ & $22.3 \pm 1$ \\
\hline Surface $\mathrm{pH}$ & 9.1 & 8.8 & 9.4 & 8.7 & 8.5 & 8.6 & 8.9 & 8.5 & $9.0 \pm 0.3$ & $8.7 \pm 0.3$ \\
\hline $\begin{array}{l}\text { Surface conductivity } \\
\qquad(\mu \mathrm{S} / \mathrm{cm})\end{array}$ & 1362 & 1621 & 1439 & 1623 & 1349 & 1623 & 1341 & 1621 & $1373 \pm 45$ & $1622 \pm 1$ \\
\hline $\begin{array}{l}\text { Surface dissolved } \\
\quad \text { oxygen (\% saturation) }\end{array}$ & 106 & 46 & 227 & 56 & 110 & 71 & 122 & 62 & $141 \pm 58$ & $59 \pm 11$ \\
\hline Secchi depth $(\mathrm{cm})$ & 38 & 13 & 20 & 13 & 18 & 15 & 26 & 15 & $26 \pm 9$ & $14 \pm 1$ \\
\hline $\mathrm{Z}_{\mathrm{eu}}$ (euphotic depth, cm) & 69 & 34 & 52 & 37 & 37 & 31 & 59 & 31 & $54 \pm 13$ & $33 \pm 3$ \\
\hline Total nitrogen $\left(\mu \mathrm{g} \mathrm{L}^{-1}\right)^{\mathrm{a}}$ & 2790 & 3694 & 2770 & 3279 & 2930 & 3222 & 2460 & 3288 & $2738 \pm 198$ & $3371 \pm 217$ \\
\hline Nitrite $\left(\mu \mathrm{g} \mathrm{L}^{-1}\right)^{\mathrm{a}}$ & 20 & 14.5 & 60 & 12.7 & 970 & 7.5 & 45 & 11.2 & $274 \pm 464$ & $11 \pm 3$ \\
\hline Nitrate $\left(\mu \mathrm{g} \mathrm{L}^{-1}\right)^{\mathrm{a}}$ & 490 & 656 & 0 & 678 & 0 & 678 & 20 & 697 & $128 \pm 242$ & $677 \pm 17$ \\
\hline Ammonia $\left(\mu \mathrm{g} \mathrm{L}^{-1}\right)^{\mathrm{a}}$ & 80 & 40 & 70 & 37 & 2150 & 40 & 70 & 38 & $593 \pm 1038$ & $39 \pm 2$ \\
\hline $\begin{array}{l}\text { Total phosphorus } \\
\qquad\left(\mu \mathrm{g} \mathrm{L}^{-1}\right)^{\mathrm{a}}\end{array}$ & 163 & 208 & 164 & 135 & 156 & 128 & 109 & 151 & $148 \pm 26$ & $156 \pm 36$ \\
\hline $\operatorname{FRP}\left(\mu \mathrm{g} \mathrm{L}^{-1}\right)^{\mathrm{a}}$ & 67.5 & 8.9 & 54.9 & 7.3 & 198.7 & 6.6 & 50.5 & 12.0 & $93 \pm 71$ & $9 \pm 2$ \\
\hline Iron $\left(\mu \mathrm{g} \mathrm{L}^{-1}\right)^{\mathrm{a}}$ & 87.5 & 17 & 86 & 5.5 & 55 & 4.5 & 79.5 & 6 & $77 \pm 15$ & $8 \pm 6$ \\
\hline
\end{tabular}

—: Data not available; FRP: filtered reactive phosphorus.

${ }^{\text {a }}$ Surface values. 


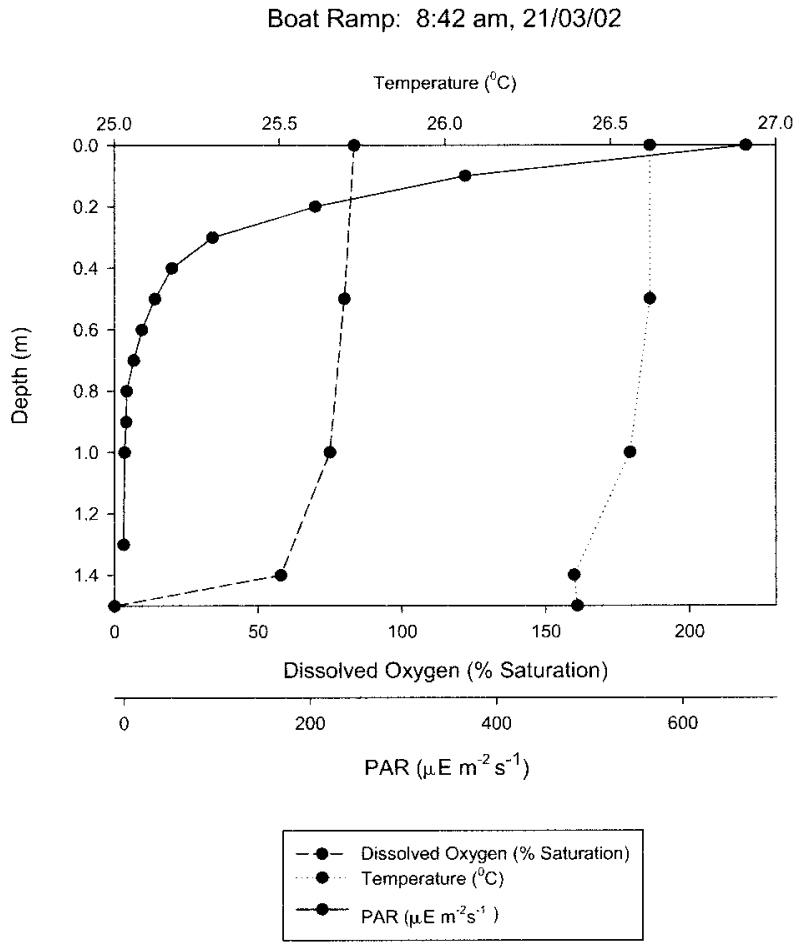

(A)

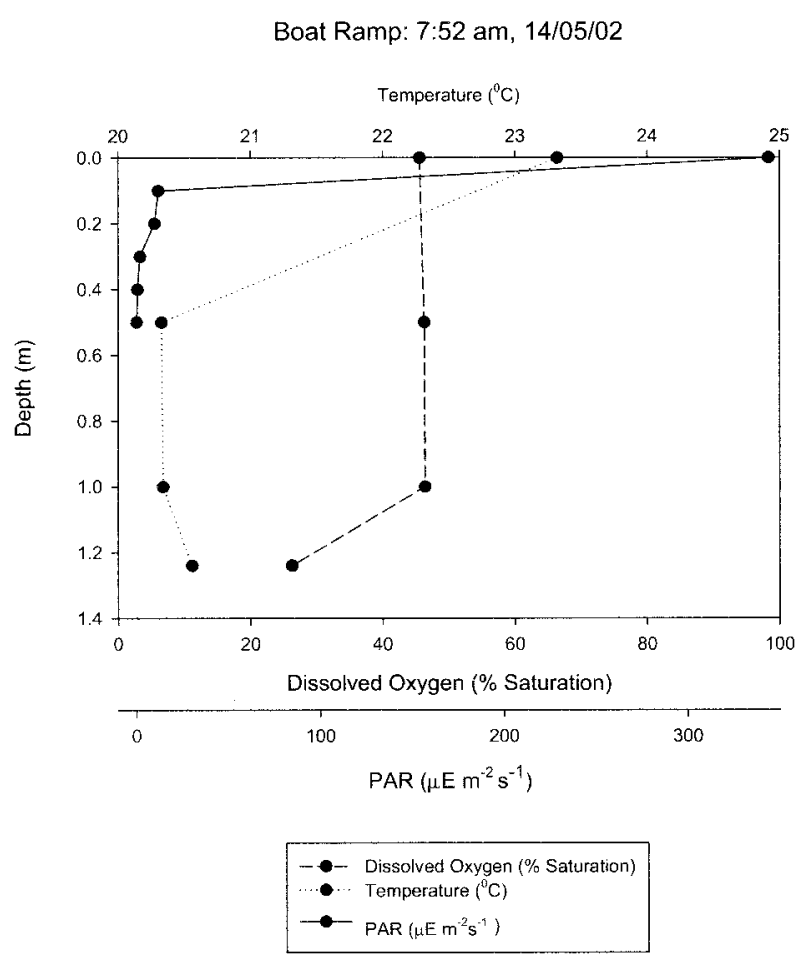

(B)

Fig. 4. Light, temperature, and oxygen profiles for the boat ramp site: (A) March 21, 2002; (B) May 14, 2002.

the filtered fractions, only nitrate increased, whereas nitrite, ammonia, and filtered reactive phosphorus (FRP) values dramatically decreased (Table II). Conductivity and $\mathrm{pH}$

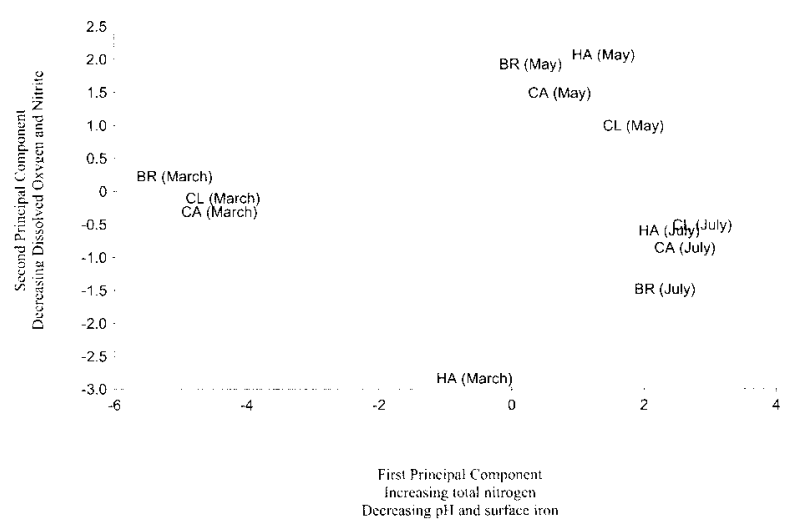

Fig. 5. Plot of principal component analysis run on logtransformed environmental data and characteristics of the algal population at Lake Elphinstone during 2002. Labels are sampling site and month.

values also experienced moderate changes between March and May.

Interactions between the physical and chemical variables of Lake Elphinstone and its phytoplankton community were examined by performing a principal component analysis (PCA) on log-transformed data (Fig. 5). The first two principal components accounted for almost $78 \%$ of variation between samples. The first principal component indicated a moderately strong positive correlation with total nitrogen and a negative correlation with $\mathrm{pH}$ and iron. The second component was negatively correlated with dissolved oxygen (DO) and nitrite. Samples were clustered according to sampling date. May and July samples, in particular, were plotted closely together, whereas HA was an outlier in the March samples.

\section{Factors Selecting for Dominance of M. panniformis}

The physical and chemical data measured at the lake during sampling in May (Table II) are particularly valuable, as these were recorded in conjunction with the presence of dense cell concentrations of toxin-producing $M$. panniformis. The species dominated under conditions of surface temperatures between $20.8^{\circ} \mathrm{C}$ and $23.2^{\circ} \mathrm{C}$, alkaline $\mathrm{pH}$ values of 8.5-8.8, and high conductivity, $>1600 \mu \mathrm{S} \mathrm{cm} \mathrm{cm}^{-1}$. Low light penetration and high levels of nutrient enrichment were also noted, with high TN $\left(>3000 \mu \mathrm{g} \mathrm{L}^{-1}\right)$ and TP $\left(155 \mu \mathrm{g} \mathrm{L}^{-1}\right)$. Nitrate and nitrite averaged 677 and $11 \mu \mathrm{g}$ $\mathrm{L}^{-1}$, respectively, with an FRP of $9 \mu \mathrm{g} \mathrm{L}^{-1}$.

\section{DISCUSSION}

\section{Phytoplankton Species Composition}

A strong similarity was found between the composition of the phytoplankton assemblages at Lake Elphinstone and 
that recorded from the Tabocas Reservoir (Brazil), the source of the Caruaru tragedy (Komárek et al., 2001). In particular, the cyanoprokaryote (Microcystis, Aphanizomenon, Pseudanabaena) and chlorophyte (Ankistrodesmus, Coelastrum, Pediastrum, Scenedesmus, Tetraëdron) genera were strikingly alike. Similar codominance patterns were also noted between Lake Elphinstone and the Paranoá Reservoir (Brazil), with dominance of Cylindrospermopsis raciborskii and periodic blooms of Microcystis aeruginosa recorded together with Raphidiopsis mediterranea (Branco and Senna, 1994).

The positioning of algal cells was affected both by the presence of gas vacuolate genera and by environmental conditions. During March, but more so in May, algal cells formed a thick surface scum, with self-shading and absorbance preventing access to light by the subsurface plankton community. Consequently, subsurface species such as $C y$ lindrospermopsis were absent in May. Increased algal abundances on the western side of the lake probably resulted from a wind-induced concentration of the gas vacuolated species (Webster, 1990). This phenomenon is particularly important at Lake Elphinstone, as the public facilities (boat ramp and swimming zones) are on the westward shore. Hence, the thick scum and its potentially high toxicity represent a health risk for lake users.

Cell concentrations recorded in July indicated the collapse of the cyanoprokaryote bloom. Unfortunately, a more detailed time line of the wax and wane of the bloom at Lake Elphinstone cannot be surmised from the three sampling occasions. Possible reasons for the collapse include there having been a combination of increased nutrient availability (nitrate, FRP) and winter cooling of the lake, preventing optimal growth conditions for cyanoprokaryotes.

\section{Toxicity}

MC was not present in Lake Elphinstone during M. botrys dominance in March. In contrast, high concentrations of MC were recorded during $M$. panniformis dominance in May. The exceptionally high toxin concentration obtained in May could partly relate to lake turbidity (Secchi depth 14 $\mathrm{cm}$, Table II) preventing light penetration and therefore reducing toxin breakdown. Also, Fitzgeorge et al. (1994) noted MC to exhibit tolerance to many environmental conditions, thus allowing capacity for toxin build-up. However, Chorus et al. (2001) argued that strain composition and competition between strains are critical in determining MC concentrations. The species shift from $M$. botrys to $M$. panniformis is therefore considered the predominant cause of the change in toxicity. This is further supported by the finding that a $M$. botrys sample collected from a private dam in Westwood, Central Queensland, was nontoxic, whereas prior to this study, M. panniformis has been associated with high MC toxicity (Komárek et al. 2001). Recently, Kur- mayer et al. (2003) studied the effects of abundant Microcystis genotypes on MC production, finding that variation in net microcystin production was predominantly a result of the proportion of microcystin-producing genotypes. The contrasting toxin production associated with $M$. botrys and $M$. panniformis may suggest genetic variability between the two species. This is interesting, as the taxonomic separation between $M$. botrys and $M$. panniformis is currently based on colony and cell morphology (Komárek and Anagnostidis 1999; Komárek et al., 2001).

The variation in toxin concentrations obtained from Lake Elphinstone highlights the need for careful sampling to assess human health risk. It is noted in the standard operational procedures for monitoring harmful algal blooms in Queensland (QDNR 2003) that algal cells can be "patchy" in distribution and subject to accumulation in downwind areas. This is critical for Lake Elphinstone, as isolated areas of highly toxic algal concentrations may need to be targeted for quantitative sampling, particularly if they are easily accessed by the public. Codd et al. (1999) recommended that thorough visual inspection of an area should form a trigger for algal cell sampling, and that sampling site selection should be linked to water usage and cell accumulation. Actual toxicity measurements are not required for health purposes in Australia (Falconer, 2001); however, both Codd et al. (1999) and Sivonen and Jones (1999) concluded that high cyanoprokaryote cell concentrations were sufficient to presume a potential risk, thus nullifying the need for actual toxicity measurement.

\section{Effects of Environmental Parameters}

The development of cyanoprokaryote blooms in Lake Elphinstone likely resulted from high nutrient and light availability, together with optimal surface temperatures for growth. Similar conclusions were reached in other studies of tropical and temperate algal blooms (Fabbro and Duivenvoorden, 1996; Scheffer et al., 1997; Dokulil and Teubner, 2000). How much a singular environmental factor affects algal blooms varies depending on the range of morphologies and physiologies of the cyanoprokaryote genera present and on their preferred optimal growth conditions (Fabbro, 1999). Dominance of particular genera relies on the provision of its ecological niche conditions. For example, Microcystis is known to predominate in lakes with diel cycles of stratification and mixis (Ganf, 1974; Reynolds, 1994; Marinho and Huszar, 2002), which were recorded at Lake Elphinstone during 2002 (White et al., unpublished).

The importance of light in regulating cyanoprokaryote species composition of shallow lake systems was examined by Havens et al. (1998). Although Microcystis requires high irradiance (Havens et al., 1998), high light attenuation was evident at Lake Elphinstone: values of the vertical attenuation coefficient of downwelling irradiance $\left(K_{d}\right)$ averaged 
8.96, 14.01, and $12.65 \mathrm{~m}^{-1}$, for March, May, and July, respectively (data not shown). Light was therefore likely to force most Microcystis cells to concentrate into surface scums. However, regular mixis of the lake was also likely to have caused frequent mixing of algal cells within the euphotic zone, thus counteracting the effects of self-shading (Rücker et al., 1997; Harding, 1997) and may have been vital in allowing the development of the exceptionally dense surface and subsurface blooms.

Light availability may also have created a spatially related cyanoprokaryote dominance pattern during March. The appearance of $R$. mediterranea (Cylindrospermopsis) in depth samples indicates a preference for low-light conditions. The near-halving of euphotic depth between March and May (Table II) is strongly suspected to have influenced the loss of $R$. mediterranea and $C$. raciborskii from the water column and, possibly, the appearance of $M$. panniformis. A similar scenario was recorded in the Paranoá Reservoir (Brazil), with increasing $M$. aeruginosa coinciding with a loss of $C$. raciborskii concentrations (Branco and Senna, 1994).

Lake Elphinstone's pH values decreased over the study, dropping from 9.0 in March to 8.7 in May and 8.4 in July (data not shown). The significance of $\mathrm{pH}$ changes on the cyanoprokaryote dominance of Lake Elphinstone, particularly between species of Microcystis, is not known.

Nutrient dynamics can impact phytoplankton assemblages by limiting rates of growth (Harris, 1986) and by affecting speciation and dominance patterns (Reynolds, 1998). Changes in nutrient availability at Lake Elphinstone may therefore have been vital in affecting the development of Microcystis-dominated blooms. In particular, dominance of Cylindrospermopsis may have been prevented in the lake because of high TP, FRP, and nitrate concentrations (Saker and Griffiths, 2001). Also, although species changes rarely are solely the result of nutrient availability (Reynolds, 1998), a possible exception to this in Lake Elphinstone was the species switch from $R$. mediterranea to $C$. raciborskii. Substantial evidence now exists to support Raphidiopsis being classified as a nutrient-influenced morphotype of $C y$ lindrospermopsis (Cronberg, 1978; McGregor and Fabbro, 2000; Li et al., 2001). In addition, the presence of Lyngbya sp. during March is potentially related to the high surface iron and phosphorus levels recorded at that time (Table II), as both have previously been identified as key nutrients for the growth of the marine species L. majuscula in Moreton Bay (Watkinson et al., 2000).

In March the physical and chemical results obtained from the HA stood apart from those collected at the remaining sampling sites (Fig. 5). This could have been related to that site being the deepest and on the leeward side or to human usage being greatly reduced on this side of the lake.

\section{Factors Selecting for Dominance of M. panniformis}

The primary distinctions between M. botrys and M. panniformis are in cell size and colony formation. The smaller cell size of $M$. panniformis (average $5.0 \mu \mathrm{m}$ in diameter) results in a larger surface area-to-volume ratio, which may have important implications in determining its preferred environmental conditions. For example, the low light penetration at Lake Elphinstone in May (Table II) could have exerted subtle pressure to switch to the species with better light-capturing morphology—such as the increased surface area for light capture in M. panniformis.

The most conspicuous changes in environmental data measured during the transition from M. botrys to M. panniformis were in temperature, light, and nutrient conditions. In particular, there was a marked decrease in the amount of FRP as a percentage of TP, dropping from approximately 92\% in March to just 5\% in May, although nitrite and ammonia also experienced large declines (Table II). Although these and other parameters were widely variable between March and May, this does not necessarily mean they were important influences in Microcystis speciationthat is, the sensitivity and response of Microcystis species to different environmental parameters may have made a minor change in one variable more important than a large change in another. Furthermore, a range of other factors not examined here may have played a role in triggering the Microcystis species switch, including interspecies competition (Elliot et al., 2002) and the availability of vitamins and trace elements.

\section{Factors Influencing $M$. panniformis Toxicity}

Variation in Microcystis toxin content may result from dominance by strains genetically determined to produce more toxin or from the effects of environmental parameters in influencing intracellular MC production or degrading extracellular toxin. The influence of environmental conditions on MC production by M. panniformis has not yet been examined. Hesse and Kohl (2000) suggested that every Microcystis strain has genotypically determined physiology and morphology, which results in strain-specific adaptations to changing environmental conditions and thus MC content. The physiology of $M$. panniformis remains virtually unstudied, although detailed toxin studies have been undertaken using other Microcystis strains.

Orr and Jones (1998) investigated toxin production by Microcystis aeruginosa, finding MC production occurred only when cell concentrations were increasing, and that cell division rates were correlated with toxin production. Bickel et al. (2000) also reported a positive correlation between the energy state and MC content of M. aeruginosa cells. These results imply that environmental parameters are capable of exerting influence on toxin production by influencing cell 
division rates, rather than by directly affecting metabolism of the toxins themselves (Orr and Jones, 1998). In Lake Elphinstone two such parameters may have been the nutrient and light conditions. Specifically, decreases in either surface iron levels $(<20 \%$ of the March values) or FRP $(<10 \%$ of March values, Table II) may have changed the energy state of $M$. panniformis. Also, the low light availability in May may have influenced the toxin-producing potential, although several authors have highlighted anomalies in studies relating to $\mathrm{MC}$ concentration under varying light conditions (e.g., Rapala et al., 1997; Hesse and Kohl, 2000).

It should be noted that the assumptions discussed here are based on a single sampling event during May 2002, and as surface $M$. panniformis concentrations were extremely high, it is equally likely that high MC values were recorded simply because of the number of cells available to produce it.

\section{CONCLUSIONS}

The variation in species dominance between sample types at Lake Elphinstone highlights the importance of choosing suitable sampling methodologies to detect all species present, especially those that are potentially toxic. Changes in the species composition of phytoplankton assemblages at Lake Elphinstone were considered to result partly from changed surface temperatures and nutrient and light availability. MC was not detected at Lake Elphinstone during dominance by $M$. botrys. In contrast, exceptionally high microcystin concentrations during the $M$. panniformis bloom may be attributed to the high cell density at time of sampling. Environmental conditions such as light and nutrient availability may also have played key roles in allowing high toxin production because of their influence on both cell division rates and on degradation of microcystin in the water column.

The authors thank Noel Sawtell for his assistance with fieldwork. Staff at the Australian Water Quality Centre and Queensland Department of Health (Scientific Services) performed toxicity tests on samples. Wendy Western provided assistance with rainfall data and liased with council and community groups. Trevor Kavanagh collected extra water samples throughout the year.

\section{REFERENCES}

Baker PD, Fabbro LD. 1999. A guide to the identification of common blue green algae (cyanoprokaryotes) in Australian freshwaters. Identification Guide No. 25. Albury, UK: Cooperative Research Centre for Freshwater Ecology.

Bickel H, Lyck S, Utkilen H. 2000. Energy state and toxin content-experiments on Microcystis aeruginosa (Chroococcales, Cyanophyta). Phycologia 39:212-218.
Branco CW, Senna PA. 1994. Factors influencing the development of Cylindrospermopsis raciborskii and Microcystis aeruginosa in the Paranoá Reservoir, Brasília, Brazil. Algol Stud 75:85-96.

Chiswell RK, Shaw GR, Eaglesham G, Smith MJ, Norris KR, Seawright AA, Moore MR. 1999. Stability of cylindrospermopsin, the toxin from the cyanobacterium, Cylindrospermopsis raciborskii: Effect of $\mathrm{pH}$, temperature and sunlight on decomposition. Environ Toxicol 14:155-161.

Codd GA, Chorus I, Burch M. 1999. Design of monitoring programmes. In: Chorus I, Bartram J, editors. Toxic cyanobacteria in water: a guide to their public health consequences, monitoring and management. London: E \& FN Spon.

Cronberg G. 1978. The Lagoa Paranoa Restoration Project. Phytoplankton Ecology and Taxonomy. Project PAHO/WHO/77/ WT/BRA/2341/04, Brazil. p 5-39.

DeBernadi R, Giussani G. 1990. Are blue-green algae a suitable food for zooplankton? An overview. Hydrobiologia 200/201: 29-41.

DeMott WR, Moxter F. 1991. Foraging on cyanobacteria by copepods: responses to chemical defenses and resource abundance. Ecology 72:1820-1834.

Dokulil MT, Teubner K. 2000. Cyanobacterial dominance in lakes. Hydrobiologia 438:1-12.

Elliot JA, Irish AE, Reynolds CS. 2002. Predicting the spatial dominance of phytoplankton in a light limited and incompletely mixed eutrophic water column using the PROTECH model. Fresh Biol 47:433-40.

Eloranta P. 1992. Fritsch Algae Collection. Leiden, The Netherlands: Inter Documentation Company.

Fabbro LD. 1999. Phytoplankton ecology in the Fitzroy River at Rockhampton, Central Queensland [PhD thesis]. Rockhampton, Central Queensland University: School of Biological and Environmental Sciences. p 347.

Fabbro LD, Duivenvoorden LJ. 1996. Profile of a bloom of the cyanobacterium Cylindrospermopsis raciborskii (Woloszynska) Seenaya and Subba Raju in the Fitzroy River in tropical central Queensland. Mar Freshwater Res 30:579-595.

Falconer IR. 2001. Toxic cyanobacterial bloom problems in Australian waters: risks and impacts on human health. Phycologia 40:228-233.

Findlay DL, Kling HJ. 1979. A species list and pictorial reference to the phytoplankton of central and northern Canada-Part II. Fisheries and Marine Service Manuscript Report No. 1503. Winnipeg, Manitoba: Western Region Fisheries and Marine Service.

Fitzgeorge RB, Clark SA, Keevil CW. 1994. Routes of intoxication. In: Codd GA, Jefferies TM, Keevil CW, Potter E, editors. Detection methods for cyanobacterial toxins. Cambridge, UK: Royal Society of Chemistry.

Ganf GG. 1974. Phytoplankton biomass and distribution in a shallow eutrophic lake (Lake George, Uganda). Oecologia 16: $9-29$.

Gell PA, Sonneman JA, Reid MA, Illman MA, Sincock AJ. 1999. An illustrated key to common diatom genera from southern Australia. Thurgoona, NSW, Australia: Cooperative Research Centre for Freshwater Ecology.

Harding WR. 1997. Phytoplankton primary production in a shal- 
low, well-mixed, hypertrophic South African lake. Hydrobiologia 344:87-102.

Harris GP. 1986. Phytoplankton ecology-Structure, function and fluctuation. London: Chapman Hall.

Havens KE, Phlips EJ, Cichra MF, Li B. 1998. Light availability as a possible regulator of cyanobacteria species composition in a shallow subtropical lake. Freshw Biol 39:547-556.

Hesse K, Kohl J. 2001. Effects of light and nutrient supply on growth and microcystin content of different strains of Microcystis aeruginosa. In: Chorus I, editor. Cyanotoxins occurrence, causes, consequences. Berlin: Springer-Verlag.

Hötzel G, Croome R. 1998. A phytoplankton methods manual for Australian rivers. Occasional Paper No. 18/98. Canberra, Australia: Land and Water Resources Research and Development Corporation.

Huszar VLM, Silva LHS, Domingos P, Marinho M, Melo S. 1998. Phytoplankton species composition is more sensitive than OECD criteria to the trophic status of three Brazilian tropical lakes. Hydrobiologia 369/370:59-71.

Jones GJ, Bourne DG, Blakely RL, Doelle H. 1994. Degradation of the cyanobacterial hepatotoxin microcystin by aquatic bacteria. Nat Toxins 2:228-235.

Komárek J, Azevedo S, Domingos P, Komarkova J, Tichy M. 2001. Background of the Caruaru tragedy: a case taxonomic study of toxic cyanobacteria. Archiv Hydrobiol Suppl (Algol Stud) 103:9-29.

Komárek J, Anagnostidis K. 1999. Cyanoprokaryota 1. Teil Chroococcales. In: Pascher A, Ettl H, Gärtner G, Heynig H, Mollenhauer D, editors. Volume 19/1, SüBwasserflora von Mitteleuropa. Jena, Stuttgart, Lübeck, Ulm, Germany: Gustav Fischer.

Kurmayer R, Christiansen G, Chorus I. 2003. The abundance of microcystin-producing genotypes correlates positively with colony size in Microcystis sp. and determines its microcystin net production in Lake Wannsee. Appl Environ Microbiol 69:787795.

Li R, Carmichael W, Brittain S, Eaglesham G, Shaw G, Liu Y, Watanabe M. 2001. First report of the cyanotoxins cylindrospermopsin and deoxycylindrospermopsin from Raphidiopsis curvata (Cyanobacteria). J Phycol 37:1121-1126.

Ling HU, Tyler PA. 1986. A limnological study of the Alligator Rivers Region. II. Freshwater algae, exclusive of diatoms. Canberra, Australia: Supervising Scientist for the Alligator Rivers Region. Australian Government Publishing Service.

Lirås V, Lindberg M, Nyström P, Annadotter H, Lawton L, Graf B. 1998. Can ingested cyanobacteria be harmful to the signal crayfish (Pacifastacus leniusculus), Fresh Biol 39:233-242.

Marinho MM, Huszar VLM. 2002. Nutrient availability and physical conditions as controlling factors of phytoplankton composition and biomass in a tropical reservoir (southeastern Brazil). Archiv Hydrobiol 153:443-468.

McGregor GB, Fabbro LD. 2001. A Guide to the identification of Australian freshwater planktonic Chroococcales (cyanoprokaryota). Identification Guide No. 39. Albany, Cooperative Research Centre for Freshwater Ecology.
McGregor GB, Fabbro LD. 2000. Dominance of Cylindrospermopsis raciborskii (Nostocales, cyanoprokaryota) in Queensland tropical and subtropical reservoirs: implications for monitoring and management. Lakes \& Reservoirs: Research and Management 5:195-205.

Orr PTJ, Jones GJ. 1998. Relationship between microcystin production and cell division rates in nitrogen-limited Microcystis aeruginosa cultures. Limnol Oceanogr 43:1604-1614.

Prescott GW. 1951. Algae of the Western Great Lakes Area. Dubuque, Iowa: Wm. C. Brown Company. p 977.

Prescott GW. 1978. How to know the freshwater algae. Dubuque, Iowa: Wm. C. Brown Company.

[QDNR] Queensland Department of Natural Resources and Mines. 2003. Queensland harmful algal bloom operational procedures. Rocklea, Australia: Harmful Algal Blooms Steering Committee, QNDR. p 34.

Rapala J, Sivonen K, Lyra C, Niemela S. 1997. Variation of microcystins, cyanobacterial hepatotoxins, in Anabaena spp. as a function of growth stimuli. Appl Environ Microbiol 63:22062212.

Ressom R, San Soong F, Fitzgerald J, Turczynowicz L, El Saadi O, Roder D, Maynard T, Falconer I. 1994. Health effects of toxic cyanobacteria (blue green algae). Canberra, Australia: National Health and Medical Resources Council.

Reynolds CS. 1998. What factors influences the species composition of phytoplankton in lakes of different trophic status? Hydrobiologia 369/370:11-26.

Reynolds CS. 1994. The long, the short and the stalled: on the attributes of phytoplankton selected by physical mixing in lakes and rivers. Hydrobiologia 289:9-21.

Rücker J, Wiedner C, Zippel P. 1997. Factors controlling the dominance of Planktothrix agardhii and Limnothrix redeki in eutrophic shallow lakes. Hydrobiologia 342/343:107-115.

Saker ML, Griffiths DJ. 2001. Occurrence of blooms of the cyanobacterium Cylindrospermopsis raciborskii (Woloszynska) Seenayya and Subba Raju in a north Queensland domestic water supply. Mar Freshwater Res 52:907-915.

Scheffer M, Rinaldi S, Gragnani A, Mur LR, Van-Nes EH. 1997. On the dominance of filamentous cyanobacteria in shallow, turbid lakes. Ecology 78:272-282.

Shapiro J. 1990. Current beliefs regarding dominance by bluegreens: the case for importance of $\mathrm{CO}_{2}$ and $\mathrm{pH}$. Verh Internat Verein Limnol 24:38-54.

Sivonen K, Jones G. 1999. Cyanobacterial toxins. In: Chorus I, Bartram J, editors. Toxic cyanobacteria in water. London: E \& FN Spoon.

Utkilen H, Gjølme N. 1995. Iron-stimulated toxin production in Microcystis aeruginosa. Appl Environ Microbiol 61:797-800.

Watkinson AJ, Dennison WC, O'Neil JM, Hewson I. 2000. Blooms of the marine cyanobacterium Lyngbya majuscula in Deception Bay: potential implications of hydric soil disturbance. Acid Sulfate Soils: Environmental Issues, Assessment and Management Technical Papers, Brisbane, Australia, June 2000.

Webster I. 1990. Effect of wind on the distribution of phytoplankton cells in lakes. Limnol Oceanog 35:989-1001. 